\title{
Development of Specific Recombinant Monoclonal Antibodies Against the Lipopolysaccharide of Ralstonia solanacearum Race 3
}

\author{
Remko A. Griep, Charlotte van Twisk, José R. C. M. van Beckhoven, Jan M. van der Wolf, and Arjen Schots
}

First, second, and fifth authors: Laboratory for Monoclonal Antibodies, P.O. Box 8123, 6700 ES Wageningen, the Netherlands; and third and fourth authors: DLO Research Institute for Plant Protection (IPO), P.O. Box 9060, 6700 GW Wageningen, the Netherlands. Accepted for publication 20 April 1998.

\begin{abstract}
Griep, R. A., van Twisk, C., van Beckhoven, J. R. C. M., van der Wolf, J. M., and Schots, A. 1998. Development of specific recombinant monoclonal antibodies against the lipopolysaccharide of Ralstonia solanacearum race 3 . Phytopathology 88:795-803.

Recombinant single-chain antibodies (scFvs) against the lipopolysaccharide of Ralstonia solanacearum (biovar 2, race 3) were successfully selected by phage display from a large combinatorial antibody library. Characterization with regard to cross-reaction and use in routine immunoassays showed that the selected antibodies had improved characteristics when compared with the polyclonal antiserum that is currently used for brown rot
\end{abstract}

ABSTRACT diagnosis of potato in the Netherlands. The isolated monoclonal scFvs reacted in both enzyme-linked immunosorbent assay (ELISA) and immunofluorescence cell staining with all race 3 strains tested, but with only some strains belonging to other races. Furthermore, only a few cross-reactions with saprophytic bacteria, which also cross-reacted with polyclonal antisera, were observed. Using ELISA, one of the recombinant antibodies detected as few as $5 \times 10^{3}$ bacteria in potato tuber extracts. Therefore, this antibody is potentially useful for detection of $R$. solanacearum race 3 .

Additional keywords: bacterial wilt, Burkholderia solanacearum, Pseudomonas solanacearum.
Ralstonia solanacearum is the causal organism of bacterial wilt and can infect over 450 different plant species including many economically important crops (7). The genus $R$. solanacearum (formerly Pseudomonas solanacearum) can be classified into three races (designated according to host-range specificity) or grouped into five biovars on the basis of utilization of disaccharides and hexose alcohols. Race 3, nearly synonymous with biovar 2, forms a homogeneous group (26), and its host range is restricted to potato, eggplant, and tomato. Race 3 is more adapted to temperate regions and is responsible for recent outbreaks of potato brown rot disease in different countries in Europe (27).

Quarantine measures have been taken in many countries to minimize the risk of introduction and spreading of the potato brown rot pathogen. Serological techniques such as enzyme-linked immunosorbent assay (ELISA), immunofluorescence cell staining (IF), and immunofluorescence colony staining (IFC) are commonly used to monitor the presence of the pathogen in potatoes and in the environment. In general, they are considered to be a good compromise between sensitivity and specificity of detection, and between ease and expense of application $(5,22,25)$.

So far, only polyclonal antibodies (PAbs) against whole or glutaraldehyde-fixed cells of $R$. solanacearum race 3 have been used in certification and risk assessment programs $(5,11)$. However, the occurrence of false-positive reactions due to the presence of crossreacting saprophytic bacteria in the extracts is considered a serious drawback to the use of PAbs. In IF, up to $3 \%$ false-positive reactions were recorded (11), while in ELISA, the frequency of false-positive reactions can sometimes exceed this level (J. G. Elphinstone, personal communication). Consequently, positive reactions need to be followed by confirmation assays, for which often tedious and time-consuming bioassays have to be used.

Corresponding author: A. Schots; E-mail address: arjen.schots@1ma.nema.wau.nl

Publication no. P-1998-0617-01R

(C) 1998 The American Phytopathological Society
In contrast to PAbs, hybridoma-derived monoclonal antibodies (MAbs) recognize only one epitope and, thus, a higher level of specificity is feasible. Attempts to produce MAbs against $R$. solanacearum were successful $(1,2,8,22)$. However, these MAbs were not developed for brown rot diagnosis in potatoes and have limited usefulness in this regard. The species-specific immunoglobulin M MAb Ps1, raised by Alvarez et al. $(1,2)$, reacted with extracellular polysaccharide-I in a very sensitive immunoassay (17), but failed to react with nonmucoid mutants (2) that can still be pathogenic (31). Moreover, MAb Ps1 is not useful for IFC in agarose plates, because its large molecular mass $(900 \mathrm{kDa})$ reduces gel diffusion and slows down staining and washing procedures. The MAbs developed by $\mathrm{He}(8)$ reacted with races 1 and 2, but not with race 3 strains (8). Strain-specific MAbs that do not crossreact with the most closely related species (R. picketti, $R$. syzygii, Burkholderia cepacia, or the banana blood disease bacterium [BBD]) were developed successfully by Robinson-Smith et al. (22). However, these MAbs were not useful for certification of potato propagation material, because they did not react with 11 of $23 R$. solanacearum strains tested, including two race 3 strains. In addition, they did not react in IF techniques, and a 100-fold decrease in sensitivity was observed in ELISA when PAbs were replaced by MAbs.

The difficulties mentioned above in developing a $R$. solanacearum race 3-specific MAb that is suited for potato brown rot diagnosis using ELISA, IF, and IFC techniques might be caused by inefficient exploitation of the immune repertoire in the hybridoma technique. Although the available (mouse) antibody repertoire is estimated to include over $10^{8}$ different antibodies, usually only a few thousand different hybridoma clones are obtained, of which, on the average, less than $1 \%$ produce antigen-binding antibodies. Thus, the probability of selecting MAbs of sufficient specificity and affinity for use in a diagnostic assay is low.

These diversity and efficiency problems were solved by recent advances in molecular immunology (Fig. 1). Forced cloning of antibody variable heavy $\left(\mathrm{V}_{\mathrm{H}}\right)$ and light $\left(\mathrm{V}_{\mathrm{L}}\right)$ chain genes by reversetranscription polymerase chain reaction (RT-PCR) $(20,24)$ allowed 
amplification of the DNA encoding the antibody repertoire. Expression of variable antibody fragments (Fv) in Escherichia coli as single-chain $\mathrm{Fv}(\mathrm{scFv})$ molecules was enabled by coupling $\mathrm{V}_{\mathrm{H}}$ and $\mathrm{V}_{\mathrm{L}}$ domains with a flexible peptide linker (10). Cloning of a pool of scFv-encoding genes, in which the $\mathrm{V}_{\mathrm{H}}$ and $\mathrm{V}_{\mathrm{L}}$ domains were randomly combined, allowed the generation of large combinatorial antibody libraries. Today combinatorial libraries of over $10^{10}$ different antibodies have been constructed $(6,30)$. This, in combination with the display of functional antigen-binding fragments on the tips of filamentous phage $(9,16)$, created a powerful system to select specific MAbs. It was shown that this phage-display system (Fig. 2) allowed direct selection (panning) of rare specificities from combinatorial antibody libraries through successive rounds of phage growth and selection for antigen binding without the need for immunization $(6,30)$, i.e., without the use of experimental animals.

In this study, the versatility of the phage-display system was challenged for the selection of $R$. solanacearum-specific MAbs. To achieve this, phages derived from a large naive human combinatorial antibody library (30) were panned against purified lipopolysaccharides (LPS) of $R$. solanacearum, and the expressed scFvs were characterized by ELISA and IF.

\section{MATERIALS AND METHODS}

Bacterial strains and growth conditions. E. coli strains used for the isolation of recombinant antibodies were TG1 (K12, $\Delta$ (lacpro), sup $\mathrm{E}$, thi, hsd $\mathrm{D} 5 / \mathrm{F}^{\prime}$ tra $\mathrm{D} 36$, pro $\mathrm{A}^{+} \mathrm{B}^{+}$, lacl ${ }^{\mathrm{q}}$, lac $\left.\mathrm{Z} \Delta \mathrm{M} 15\right)$ for selection of specific phage antibodies and $\mathrm{HB} 2151$ (K12, ara, $\Delta$ lacpro, thi $/ \mathrm{F}^{\prime} /$ pro $\mathrm{A}^{+} \mathrm{B}^{+}$, lac $\mathrm{I}^{\mathrm{q}} \mathrm{Z} \Delta \mathrm{M} 15$ ) for production of soluble scFvs.

Strains of $R$. solanacearum and strains of bacteria that crossreacted with polyclonal antisera to $R$. solanacearum were pre- served at $-80^{\circ} \mathrm{C}$ on beads (Protect Bacterial Preservers; Biotrading Benelux, Wilnis, the Netherlands) in $8 \mathrm{mg}$ of $15 \%$ glycerin per $\mathrm{ml}$ of LabLemco broth (CM15; Oxoid, Hampshire, United Kingdom). For each experiment, bacteria were grown for 48 to $72 \mathrm{~h}$ at $27^{\circ} \mathrm{C}$ on plates of Trypticase soy broth (30 g/liter; BBL Microbiology Systems, Becton Dickinson, Cockeysville, MD), and prior to use, were transferred to slopes of growth factor agar $\left(2.3 \mathrm{mM} \mathrm{K}_{2} \mathrm{HPO}_{4}\right.$, $0.2 \mathrm{mM} \mathrm{MgSO}_{4} \cdot 7 \mathrm{H}_{2} \mathrm{O}, 1.7 \mathrm{mM} \mathrm{NaCl}, 4.3 \mathrm{mM} \mathrm{NH}_{4} \mathrm{H}_{2} \mathrm{PO}_{4}, 5 \mathrm{mM}$ glucose, $0.5 \%$ [wt/vol] yeast, and $1.5 \%$ [wt/vol] agar, $\mathrm{pH} 7.2)$ and grown for $24 \mathrm{~h}$ at $27^{\circ} \mathrm{C}$. Characterization of cross-reacting bacteria by fatty acid analysis using the Microbial Identification System (Microbial ID, Newark, DE) was done by J. G. Elphinstone (Central Science Laboratory, York, United Kingdom).

Purification of LPS. The purification of LPS from $R$. solanacearum (strain 1609 race 3, biovar 2) was performed according to De Weger et al. (4).

Panning procedure. Selection of phage antibodies (PhAbs, phages expressing functional scFvs on their surface) from the human combinatorial antibody library was performed according to Vaughan et al. (30) with a few modifications. Immunosorbent tubes (Maxi-sorb; Nunc, Roskilde, Denmark) were coated with $500 \mu \mathrm{g}$ of LPS $\left(125 \mu \mathrm{g} / \mathrm{ml}\right.$ in $50 \mathrm{mM} \mathrm{NaHCO}$, pH 9.8) for $18 \mathrm{~h}$ at $4^{\circ} \mathrm{C}$. The tubes were washed twice with phosphate-buffered saline (PBS) and blocked with PBM-2\% (PBS containing 2\% skimmed milk powder) for $30 \mathrm{~min}$ at room temperature. Simultaneously, $2 \mathrm{ml}$ of a stock derived from the Vaughan library (30) containing $2.5 \times 10^{13}$ PhAbs was mixed with $2 \mathrm{ml}$ of PBM-4\% and preincubated for 30 min. After removing the blocking solution from the tubes and washing with PBS, $4 \mathrm{ml}$ of PhAbs was added to the tubes. PhAbs were allowed to bind to LPS for $30 \mathrm{~min}$ on a roller bench and for another $90 \mathrm{~min}$ without rotation. Free PhAbs were removed by wash-
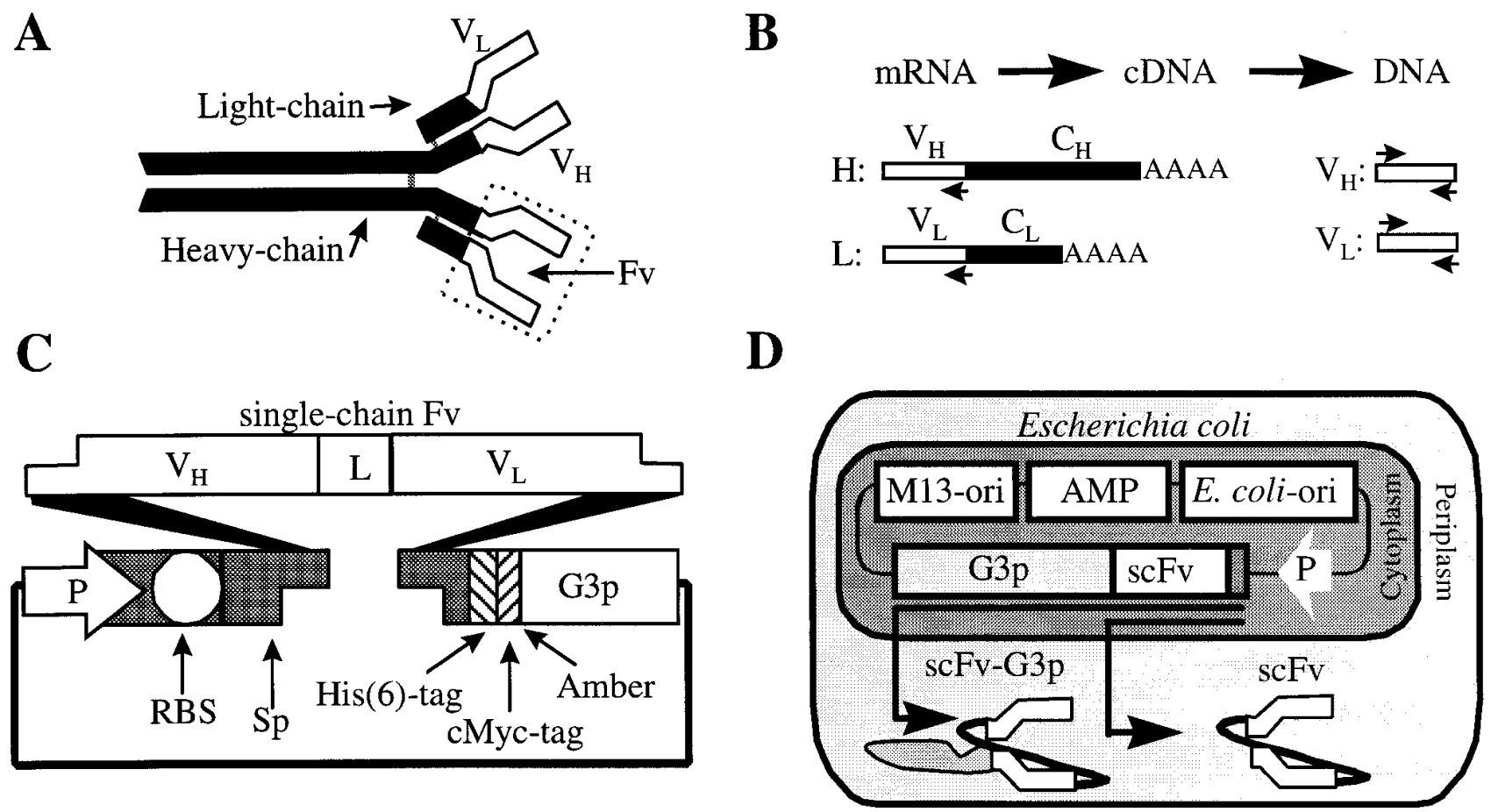

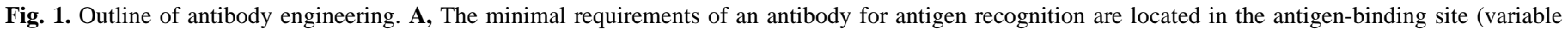

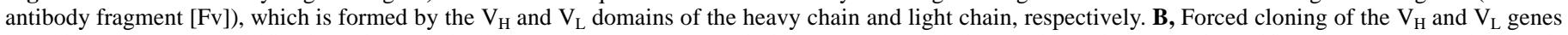

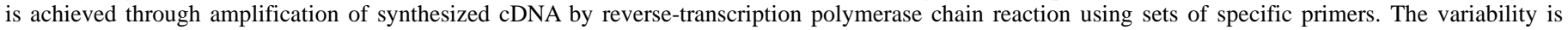

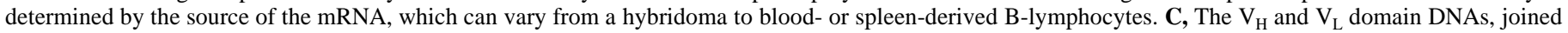

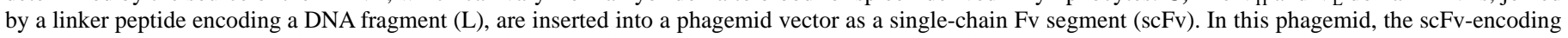

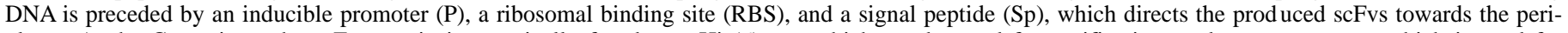

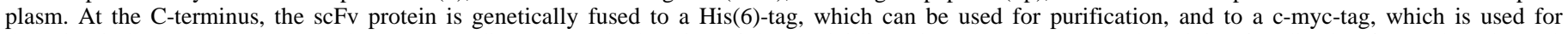

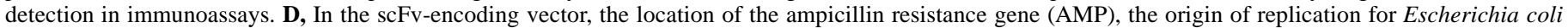

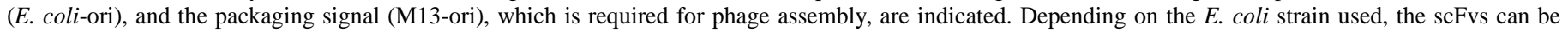

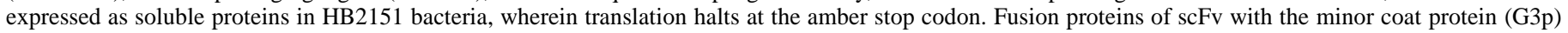
of filamentous phage fd are obtained from TG1 bacteria in which translation proceeds through the amber codon. 
ing the tubes 10 times with PBS containing 0.1\% Tween-20 (PBST) and another 10 times with PBS to remove the detergent. Bound PhAbs were eluted by adding $1 \mathrm{ml}$ of $0.1 \mathrm{M}$ triethylamine (TEA) and incubation for $10 \mathrm{~min}$ on a roller bench. After collecting the TEA eluent, the $\mathrm{pH}$ was neutralized by the addition of $0.5 \mathrm{ml}$ of $1 \mathrm{M}$ Tris- $\mathrm{HCl}, \mathrm{pH}$ 7.4. One milliliter of the eluted $\mathrm{PhAbs}$ was used to infect $5 \mathrm{ml}$ of E. coli TG1 bacteria (or HB2151 in the final panning round), which were freshly grown to an optical density at $600 \mathrm{~nm}$ $\left(\mathrm{OD}_{600}\right)$ of 0.5 in $2 \times$ tryptone yeast $(2 \mathrm{TY})$ broth (23). After infection for $30 \mathrm{~min}$ in a water bath at $37^{\circ} \mathrm{C}$ without shaking to allow optimal infection, the $E$. coli cells were pelleted (3,000 $\times g$ for $10 \mathrm{~min})$ and resuspended in $1 \mathrm{ml}$ of $2 \mathrm{TY}$ broth containing $100 \mu \mathrm{g}$ of ampicillin and 2\% glucose (2TYB-AMP-2\%Glu) per ml. To establish the number of eluted PhAbs, $50 \mu$ was taken from this suspension, and serial dilutions were plated on 2TY agar plates containing $100 \mu \mathrm{g}$ of ampicillin and $2 \%$ glucose (2TYA-AMP-2\%Glu) per ml. The remaining $950 \mu \mathrm{l}$ was plated separately on $225 \times 225$-mm 2 TYA-AMP$2 \%$ Glu plates, and the bacteria were grown for $18 \mathrm{~h}$ at $30^{\circ} \mathrm{C}$.

This procedure was carried out four times in succession using PhAbs prepared as described below for the second, third, and fourth panning round. To increase the specificity and reduce the background, the stringency was increased after the second panning round. The amount of antigen that was used for coating was then decreased from 125 to $10 \mu \mathrm{g} / \mathrm{ml}$ in the third round and to $1 \mu \mathrm{g} / \mathrm{ml}$ in the final panning round. Simultaneously, the stringency was further enhanced by increasing the number of washings from 20 times after the second panning round to 40 times in the subsequent rounds of selection.

Preparation of PhAbs for subsequent panning rounds. The bacteria derived from a previous panning round were scraped from the plate $(225 \times 225 \mathrm{~mm})$ and resuspended in $15 \mathrm{ml}$ of $2 \mathrm{TYB}-$
AMP-2\%Glu. From these bacteria, $14.5 \mathrm{ml}$ was used to prepare a freezer stock (22), $500 \mu \mathrm{l}$ was used to inoculate $50 \mathrm{ml}$ of 2TYBAMP- $1 \% \mathrm{Glu}$, and the bacteria were grown at $37^{\circ} \mathrm{C}$ with shaking (250 rpm). When an $\mathrm{OD}_{600}$ of 0.5 was reached, $10^{11}$ helper phages (M13K07; Pharmacia Biotechnology, Inc., Uppsala, Sweden) were added (multiplicity of infection $=20$ ). The $15-\mathrm{ml}$ tube containing the mixture was put in a water bath at $37^{\circ} \mathrm{C}$ without shaking to allow for optimal infection. After $30 \mathrm{~min}$, the bacteria were pelleted $(2,100 \times g$ for $10 \mathrm{~min})$ and resuspended in $25 \mathrm{ml}$ of 2TYB$\mathrm{AMP}$ and $25 \mu \mathrm{g}$ of kanamycin per $\mathrm{ml}$. The bacteria were transferred to a 250-ml Erlenmeyer flask and grown for $18 \mathrm{~h}$ at $30^{\circ} \mathrm{C}$ with shaking $(250 \mathrm{rpm})$. The $25-\mathrm{ml}$ overnight culture was harvested, and the bacteria were removed by centrifugation $(2,100 \times g$ for $20 \mathrm{~min}$ ). The PhAbs in the supernatant were precipitated by adding $5 \mathrm{ml}$ of $20 \%$ polyethylene glycol 6000 and $2.5 \mathrm{M} \mathrm{NaCl}$ and thoroughly mixed for $1 \mathrm{~h}$ at $4^{\circ} \mathrm{C}$. The precipitated $\mathrm{PhAbs}$ were pelleted $(2,100 \times g$ for $20 \mathrm{~min})$ and resuspended in $1 \mathrm{ml}$ of sterile PBS. Usually $5 \times 10^{12} \mathrm{PhAbs}$ per $\mathrm{ml}$ were produced, as assayed by infection of strain TG1 and plating for ampicillin resistance. The derived $\mathrm{PhAbs}$ were stored at $4^{\circ} \mathrm{C}$ until use in the next panning round or in phage ELISA.

MvaI fingerprinting. To analyze the diversity of the selected $\mathrm{PhAbs}$, restriction fragment length polymorphism (RFLP) fingerprinting was performed on PCR-amplified scFv DNA. Single colonies were picked and grown for $4 \mathrm{~h}$ in 2TYB-AMP-2\%Glu. From these suspensions, $2 \mu \mathrm{l}$ was taken and added to a $48-\mu \mathrm{l}$ PCR mix containing $2.5 \mu \mathrm{M}$ dNTPs, $0.25 \mathrm{U}$ of Super Taq DNA polymerase (HT Biotechnology, Cambridge, United Kingdom), $10 \mu \mathrm{M}$ forward primer (5'-AGG AAA CAG CTA TGA CCA TGA TTA CGC CAA G-3'), $10 \mu \mathrm{M}$ reverse primer (5'-GCC CAA TAG GAA CCC ATG TAC CGT AAC ACT G-3'), $2 \mathrm{mM} \mathrm{MgCl}_{2}$, and
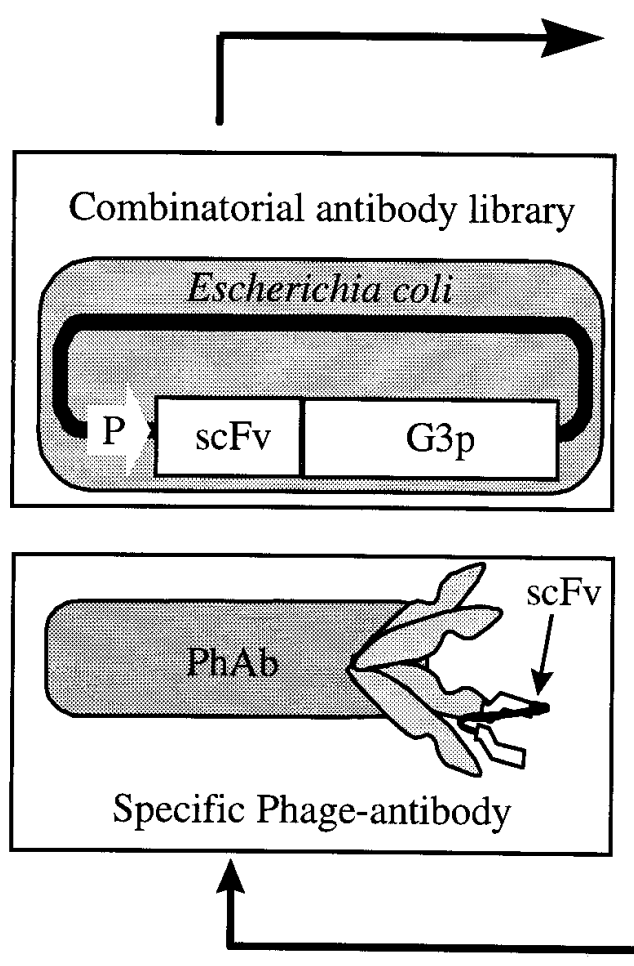
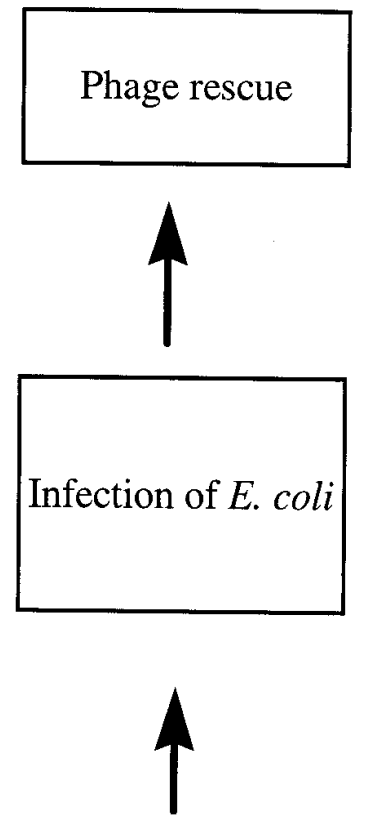

Elution
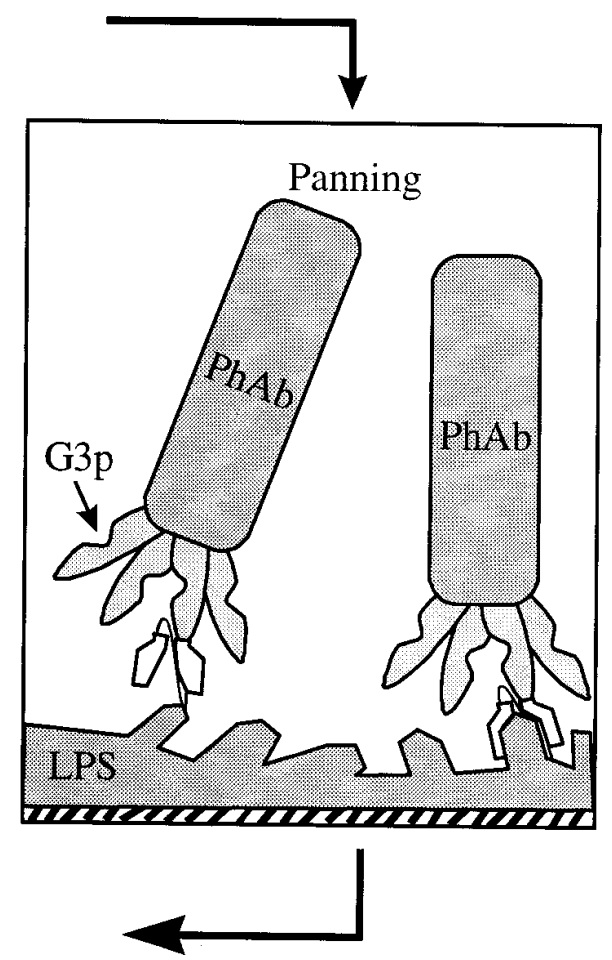

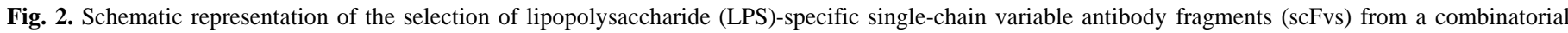

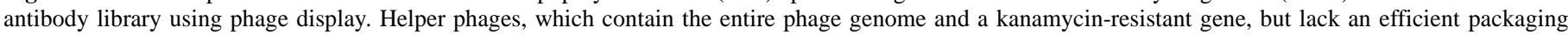

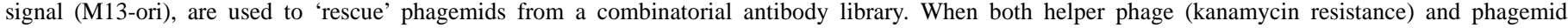

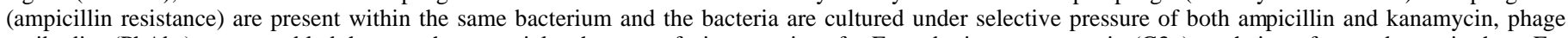

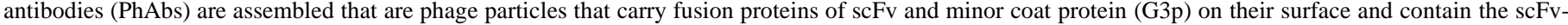

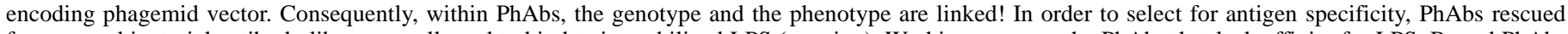

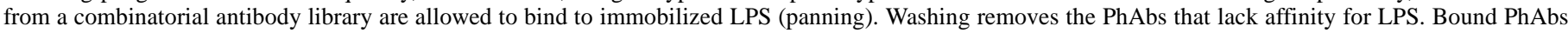
are eluted, and the selected PhAbs are enriched by sequential rounds of panning until the desired affinity is obtained. 
$50 \mathrm{mM}$ Tris-HCl, $\mathrm{pH}$ 8. In a thermal cycler (Perkin Elmer Cetus, Norwalk, CT), 25 cycles $\left(1 \mathrm{~min}\right.$ at $94^{\circ} \mathrm{C}$ and $2 \mathrm{~min}$ at $72^{\circ} \mathrm{C}$ ) were performed. From the PCR mix, $20 \mu \mathrm{l}$ was added to $37.5 \mu \mathrm{l}$ of $\mathrm{H}_{2} \mathrm{O}$ and $6.5 \mu \mathrm{l}$ of buffer $\mathrm{H}$ (Boehringer $\mathrm{GmbH}$, Mannheim, Germany). After mixing, $10 \mathrm{U}$ of $M v a \mathrm{I}$ (Boehringer $\mathrm{GmbH}$ ) was added, and the mixture was incubated for $18 \mathrm{~h}$ at $37^{\circ} \mathrm{C}$. The $M v a \mathrm{I}$ digestion patterns were analyzed on a 3\% FMC Metaphor agarose gel (Epicentre Technologies, Madison, WI).

Production and purification of scFvs. E. coli HB2151 was cultured according to Kerschbaumer et al. (12) and cells were pelleted. After incubation $\left(5 \mathrm{~min}\right.$ at $0^{\circ} \mathrm{C}$ ) of the bacteria with $1 / 20$ volume (referring to the original culture size) of $50 \mathrm{mM}$ Tris- $\mathrm{HCl}$ buffer, $\mathrm{pH} 8$, containing $30 \%$ sucrose and $1 \mathrm{mM}$ EDTA, the scFvs were extracted $\left(45 \mathrm{~min}\right.$ at $0^{\circ} \mathrm{C}$ ) from the periplasm with $1 / 20$ volume (referring to the original culture size) of $5 \mathrm{mM} \mathrm{MgSO}_{4}$. Secreted scFvs were purified from the periplasmic fraction using immobilized metal affinity chromatography (IMAC) according to Lindner et al. (15).

Routine protocol for the extraction of potato tubers. Potato extracts were made according to the legislation of the European Community (97/647/EG). Briefly, maceration buffer (4.26 $\mathrm{g}$ of $\mathrm{Na}_{2} \mathrm{HPO}_{4}$ and $2.72 \mathrm{~g}$ of $\mathrm{KH}_{2} \mathrm{PO}_{4}\left[50 \mathrm{mM} \mathrm{PO}_{4}\right]$ per liter of distilled water, $\mathrm{pH}$ 7.0) was added until 200 heel ends were fully submerged. The sample was incubated for $18 \mathrm{~h}$ at $6^{\circ} \mathrm{C}$ with shaking (75 rpm) and then passed through a $40-$ to $100-\mu \mathrm{m}$ filter. Filtrate was collected after washing the filter with maceration buffer and centrifuged for $15 \mathrm{~min}$ at $10,000 \times g$ at $6^{\circ} \mathrm{C}$. The pellet was resuspended in $1 \mathrm{ml}$ of $10 \mathrm{mM}$ phosphate buffer $(2.7 \mathrm{~g}$ of $\mathrm{Na}_{2} \mathrm{HPO}_{4} \cdot 12 \mathrm{H}_{2} \mathrm{O}$ per liter and $0.4 \mathrm{~g}$ of $\mathrm{NaH}_{2} \mathrm{PO}_{4} \cdot 2 \mathrm{H}_{2} \mathrm{O}$ per liter, $\mathrm{pH}$ 7.2). Glycerin was added to a final concentration of $15 \%$, and samples were stored at $-70^{\circ} \mathrm{C}$ until use.

ELISA. A phage ELISA was used to assess the specificity of the PhAbs after each round of panning according to standard methods $(3,28)$, in which the plates were washed four times with PBST between each incubation step. Briefly, a 96-well microtiter plate was coated with LPS $\left(2 \mu \mathrm{g} / \mathrm{ml}\right.$ in $\left.0.1 \mathrm{M} \mathrm{NaCO}_{3}\right)$ for $2 \mathrm{~h}$ at $37^{\circ} \mathrm{C}$ at $100 \mu \mathrm{l}$ per well. After blocking with PBSTM-5\% (PBST containing 5\% skimmed milk powder) at $200 \mu \mathrm{l}$ per well, the plates were incubated for $1 \mathrm{~h}$ with PhAbs in PBSTM-1\% at $100 \mu \mathrm{l}$ per well. After that, the plates were incubated with anti-M13 MAbs at $100 \mu \mathrm{l}$ per well (MAb 12E4 diluted to $5 \mu \mathrm{g} / \mathrm{ml}$ in PBSTM-1\%) and finally with rat anti-mouse PAbs conjugated to alkaline phosphatase (RaAM-AP; Jackson Immuno Research Laboratories, Inc., Westgrove, PA) diluted 1:2,000 in PBSTM-1\%. The reaction with LPS was visualized by incubation with $p$-nitrophenyl phosphate substrate (p-NPP).

An indirect ELISA was used to assess the specificity of the recombinant scFvs according to standard methods $(3,28)$, in which the plates were washed three times with PBST between each incubation step. Briefly, a 96-well microtiter plate was coated, either with LPS $\left(2 \mu \mathrm{g} / \mathrm{ml}\right.$ in $\left.0.1 \mathrm{M} \mathrm{NaCO}_{3}\right)$ or with bacteria $\left(\mathrm{OD}_{600}\right.$ of 0.1 in $0.1 \mathrm{M} \mathrm{NaCO}_{3}$ ), for $2 \mathrm{~h}$ at $37^{\circ} \mathrm{C}$ at $100 \mu \mathrm{l}$ per well. After blocking with PBSTM-5\% at $200 \mu \mathrm{l}$ per well, the plates were incubated for $1 \mathrm{~h}$ with PAbs PcA-9523 (a polyclonal antiserum that was produced against whole cells of $R$. solanacearum race 3 strain 1609 diluted 1:2,000 in PBSTM-1\%; PAb-ELISA [ELISA in which detection of $R$. solanacearum is based on polyclonal antibodies]); or scFvs (c-myc-ELISA [ELISA in which binding of scFvs to $R$. solanacearum is detected through detection of the c-myc-tag $\{18\}$ that is expressed on the $\mathrm{C}$-terminus of the $\mathrm{scFv}$ [Fig. 1C \}]) diluted in PBSTM- $1 \%$ at $100 \mu \mathrm{l}$ per well. After that, the plates were incubated at $100 \mu \mathrm{l}$ per well with goat anti-rabbit PAbs conjugated to alkaline phosphatase (diluted 1:2,000 in PBSTM-1\%; PAb-ELISA;

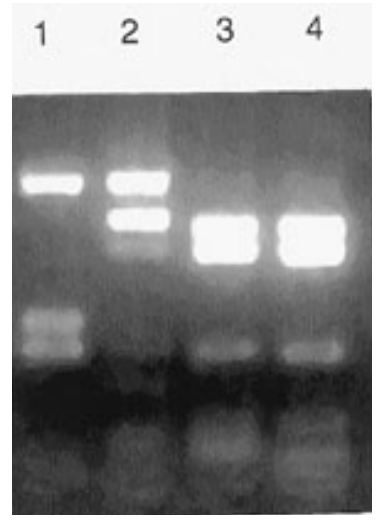

Fig. 4. Characterization of four anti-lipopolysaccharide (LPS) clones by $M v a I$ restriction fragment length polymorphism fingerprinting of the singlechain variable antibody fragments ( $\mathrm{scFv}$ )-encoding DNA: lane 1, anti-LPS 3; lane 2, anti-LPS 8; lane 3, anti-LPS 12; and lane 4, anti-LPS 13.

\section{A}
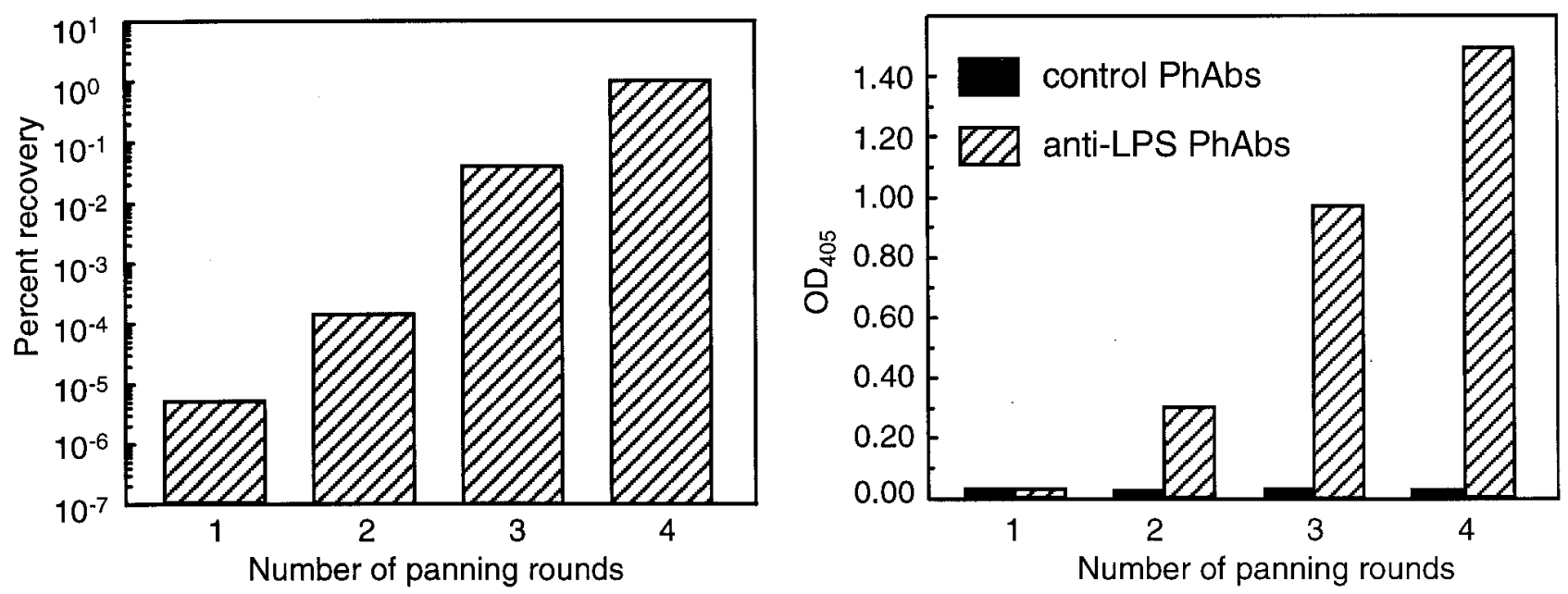

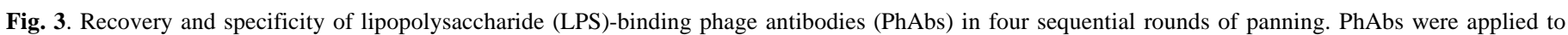

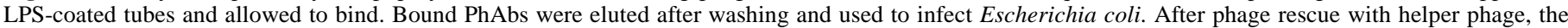

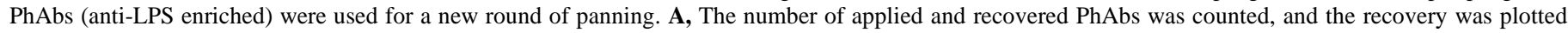

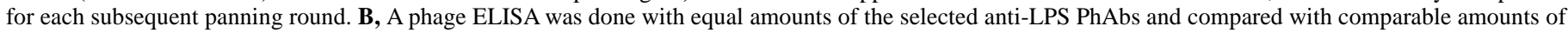
control PhAbs (derived from a panning against another antigen) to show that the binding was LPS specific. 
Sigma Chemical Co., St. Louis) or anti-c-myc MAbs (MAb 9E10 [18] diluted to $1 \mu \mathrm{g} / \mathrm{ml}$ in PBSTM-1\%; c-myc-ELISA [9]) and finally with RaAM-AP diluted 1:2,000 in PBSTM-1\%. The reaction with LPS was visualized by incubation with p-NPP.

The detection limits of the scFvs and polyclonal antiserum PcA9523 for $R$. solanacearum were determined with an indirect doubleantibody sandwich ELISA, in which the plates were washed three

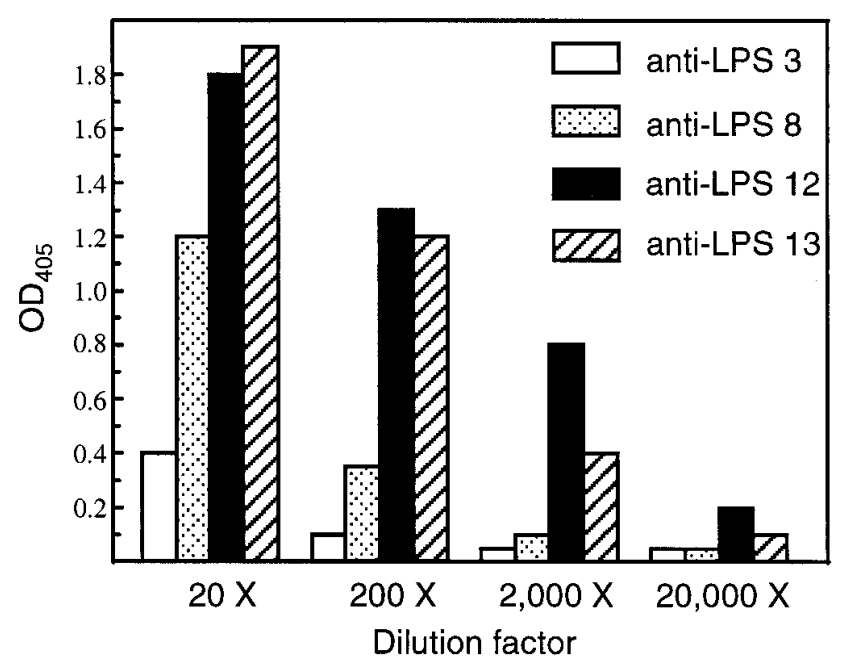

Fig. 5. Reaction of purified monoclonal single-chain variable antibody fragments (scFv) (anti-LPS 3, anti-LPS 8, anti-LPS 12, and anti-LPS 13) with lipopolysaccharide (LPS) in enzyme-linked immunosorbent assay (ELISA). ELISA plates were coated with LPS derived from Ralstonia solanacearum. scFvs were applied and the binding to LPS was detected by incubations with anti-c-myc monoclonal antibodies, rat anti-mouse polyclonal antibodies conjugated with alkaline phosphatase, and para-nitrophenylphosphate. times with PBST between each subsequent incubation step. Briefly, ELISA plates (intermediate binding capacity, cat. no. 655001; Greiner Laborteknik GmbH, Frickenhausen, Germany) were coated with PAb PcA-9523 (diluted 1:2,000 in $0.1 \mathrm{M} \mathrm{NaCO}_{3}$ ) at $100 \mu \mathrm{l}$ per well for $2 \mathrm{~h}$ at $37^{\circ} \mathrm{C}$. After blocking with PBSTM-5\% for $30 \mathrm{~min}$ at $200 \mu \mathrm{l}$ per well, the plates were incubated with 10 -fold serial dilutions of $R$. solanacearum bacteria (diluted in either PBS or potato tuber extract) at $100 \mu \mathrm{l}$ per well for $2 \mathrm{~h}$ at $37^{\circ} \mathrm{C}$. Subsequently, the plates were incubated with either PcA-9523-AP conjugate (diluted 1:2,000 in PBM) or with $\mathrm{scFv}$ anti-LPS 12 (diluted to $5 \mu \mathrm{g} / \mathrm{ml}$

TABLE 1. Comparison of single-chain variable antibody fragments (scFv) anti-lipopolysaccharide (LPS) 12 and polyclonal antiserum PcA-9523 for their detection limits for Ralstonia solanacearum race 3 in enzyme-linked immunosorbent assay (ELISA)

\begin{tabular}{|c|c|c|c|c|}
\hline \multirow{3}{*}{$\begin{array}{l}\text { R. solanacearum } \\
\text { concentration } \\
(\mathrm{CFU} / \mathrm{ml})\end{array}$} & \multicolumn{4}{|c|}{ ELISA substrates $^{\mathrm{a}}$} \\
\hline & \multicolumn{2}{|c|}{$\mathrm{p}-\mathrm{NPP}\left(\mathrm{OD}_{405}\right.$ value $)$} & \multicolumn{2}{|c|}{ FDP (relative fluorescence) } \\
\hline & anti-LPS $12^{b}$ & $\mathrm{PcA}-9523^{\mathrm{c}}$ & anti-LPS $12^{\mathrm{d}}$ & PcA-9532d \\
\hline $4 \times 10^{5}$ & $2.8^{\mathrm{e}}$ & 2.9 & 3.3 & 2.9 \\
\hline $4 \times 10^{4}$ & 0.86 & 0.9 & 0.7 & 2.5 \\
\hline $4 \times 10^{3}$ & 0.21 & 0.42 & 0.14 & 0.83 \\
\hline $4 \times 10^{2}$ & 0.15 & 0.35 & 0.10 & 0.69 \\
\hline 0 & 0.16 & 0.20 & 0.09 & 0.68 \\
\hline
\end{tabular}

a Cells of strain 1609 were suspended in phosphate-buffered saline and tested at different concentrations. The reactions were visualized using the chromatogenic substrate $p$-nitrophenyl phosphate substrate ( $\mathrm{p}$-NPP) or the fluorogenic substrate fluorescein diphosphate (FDP).

b Incubation time with substrate was $120 \mathrm{~min}$.

c Incubation time with substrate was $40 \mathrm{~min}$.

d Incubation time with substrate was $80 \mathrm{~min}$.

e The data were obtained from a representative experiment and the standard deviations $(n=2)$ were smaller than 0.1 for all presented data. ELISA signals that exceeded at least threefold the background value were regarded as a positive response.
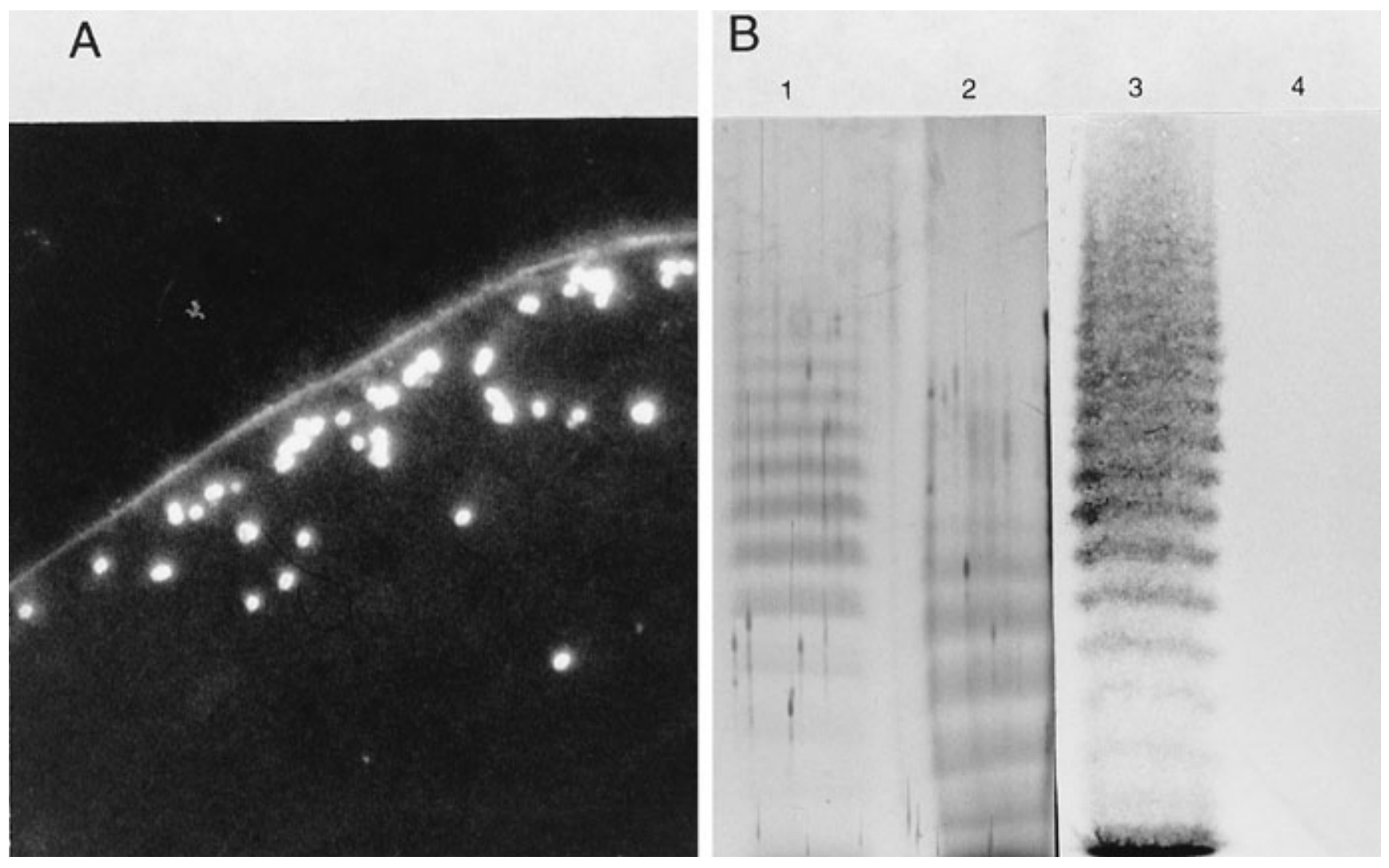

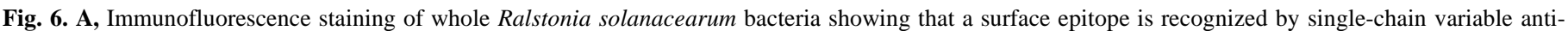

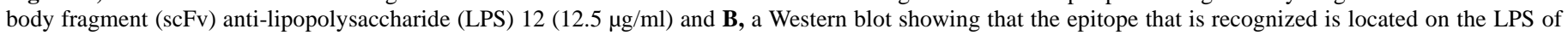

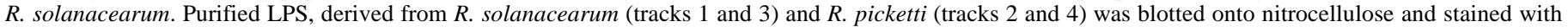
silver (Bio-Rad Laboratories) or with scFv anti-LPS 12 (tracks 3 and 4), respectively. 
in PBM-2\%) at $100 \mu \mathrm{l}$ per well for $1 \mathrm{~h}$ at $37^{\circ} \mathrm{C}$. This was followed by incubations with antic-myc MAb 9E10 (diluted to $1 \mu \mathrm{g} / \mathrm{ml}$ in PBM-2\%) and RaAM-AP (diluted 1:2,000 in PBM-2\%) at $100 \mu \mathrm{l}$ per well for $1 \mathrm{~h}$. The reactions were visualized by incubation with either p-NPP or with fluorescein diphosphate (FDP) substrate. Optical densities at $405 \mathrm{~nm}$ were measured with an ELISA reader and fluorescence was measured at $510 \mathrm{~nm}$ with a fluorometer (ABI PRISM 7700 sequence detection system, Perkin-Elmer Applied Biosystems, Foster City, CA).

Western blotting. Purified LPS $(0.5 \mu \mathrm{g}$ per lane) was separated by sodium dodecyl sulfate polyacrylamide gel electrophoresis (SDSPAGE) and transferred to nitrocellulose membranes as described by van der Wolf et al. (29). Reactive groups on the membrane were blocked with PBMT-5\%. The reactivity of the scFv towards LPS was shown by incubations of the blot with anti-LPS scFv, anti-c-

TABLE 2. Values obtained in an enzyme-linked immunosorbent assay (ELISA) with single-chain variable antibody fragments $(\mathrm{scFv})$ anti-lipopolysaccharide (LPS) 12 against Ralstonia solanacearum race 3

\begin{tabular}{|c|c|c|c|c|}
\hline \multirow{3}{*}{$\begin{array}{l}R . \text { solanacearum } \\
\text { concentration } \\
(\mathrm{CFU} / \mathrm{ml})\end{array}$} & \multicolumn{4}{|c|}{ 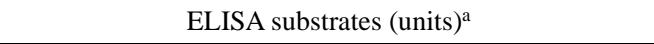 } \\
\hline & \multicolumn{2}{|c|}{$\mathrm{p}-\mathrm{NPP}\left(\mathrm{OD}_{405}\right)^{\mathrm{b}}$} & \multicolumn{2}{|c|}{ FDP (relative fluorescence) ${ }^{\mathrm{b}}$} \\
\hline & Pure culture & Tuber extract & Pure culture & Tuber extract \\
\hline $5 \times 10^{5}$ & $>3^{c}$ & $>3$ & 3.1 & 2 \\
\hline $5 \times 10^{4}$ & 1.4 & 1.1 & 1.9 & 1.6 \\
\hline $5 \times 10^{3}$ & 0.44 & 0.44 & 0.51 & 0.31 \\
\hline $5 \times 10^{2}$ & 0.33 & 0.36 & 0.19 & 0.18 \\
\hline 0 & 0.28 & 0.31 & 0.11 & 0.1 \\
\hline
\end{tabular}

a Different concentrations of $R$. solanacearum bacteria strain 1609 were suspended in phosphate-buffered saline (pure culture) or in a potato tuber extract, and the detection limits were assayed with a double-antibody sandwich ELISA. The reactions were visualized using the chromatogenic substrate $p$-nitrophenyl phosphate substrate (p-NPP) or the fluorogenic substrate fluorescein diphosphate (FDP).

${ }^{b}$ Incubation time with substrate was $120 \mathrm{~min}$.

c The data describe a typical experiment and the standard deviations $(n=2)$ were smaller than 0.1 . ELISA signals that exceeded at least threefold the background value were regarded as a positive response. myc MAb 9E10 (diluted to $10 \mu \mathrm{g} / \mathrm{ml}$ in PBM-2\%), RaAM-AP (diluted 1:2,000 in PBM-2\%), and 5-bromo-4-cloro-3-indoylphosphate/nitroblue tetrazolium chloride substrate.

IF. IF was performed according to van der Wolf et al. (29). For IF, the bacteria were coated on microscope slides and incubated with anti-LPS scFv (diluted to 12.5 to $125 \mu \mathrm{g} / \mathrm{ml}$ in PBS) and antic-myc MAb 9E10 (diluted to $30 \mu \mathrm{g} / \mathrm{ml}$ in PBS), which was conjugated with fluorescein isothiocyanate.

\section{RESULTS}

Selection of LPS-binding clones from a combinatorial antibody library. From the first panning round in which $2.5 \times 10^{13}$ PhAbs (expressing $1.4 \times 10^{10}$ different scFvs) were applied to the LPS-coated immunosorbent tube, approximately $1.5 \times 10^{6} \mathrm{PhAbs}$ were recovered (Fig. 3A). In the subsequent rounds of selection, enrichment factors of 100- to 1,000-fold were obtained as the stringency during the selection was gradually increased. The increased efficiencies of recovery during panning were paralleled by increasing signals in phage ELISA (Fig. 3B). This result indicates that phages binding to LPS were enriched during the selection procedure.

Characterization of monoclonal LPS-binding scFv. Four bacterial clones, which produced scFvs with high activity in the cmyc-ELISA (designated anti-LPS 3, anti-LPS 8, anti-LPS 12, and anti-LPS 13), were further characterized. The variability within the scFv genes was established using RFLP of PCR-amplified DNA. Four different $M v a \mathrm{I}$ restriction patterns were observed (Fig. 4). Although the patterns of anti-LPS 12 and anti-LPS 13 looked quite similar, nucleotide DNA sequencing of plasmid DNA revealed that these scFvs were different (data not shown). The four different scFvs were purified by IMAC. Anti-LPS 3 could only be purified in low amounts; the maximum yield was $50 \mu \mathrm{g} / \mathrm{liter}$, and SDSPAGE indicated that the bulk of this was degraded, as it did not have the expected molecular mass of $27 \mathrm{kDa}$ (data not shown). This was in contrast to the scFvs anti-LPS 8, 12, and 13, which yielded up to $1.5,3$, and $2.5 \mathrm{mg}$ of intact scFvs per liter, respectively.

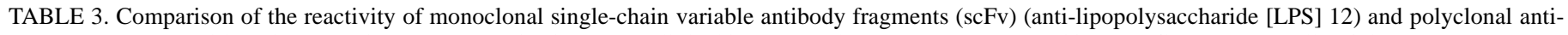
serum (PcA-9523) with Ralstonia solanacearum strains in enzyme-linked immunosorbent assay (ELISA) and immunofluorescence cell staining (IF)

\begin{tabular}{|c|c|c|c|c|c|c|c|c|c|}
\hline \multirow[b]{2}{*}{ Strain $^{\mathrm{a}}$} & \multirow[b]{2}{*}{ Country where isolated } & \multirow[b]{2}{*}{ IPO number ${ }^{b}$} & \multirow[b]{2}{*}{ Original number } & \multirow[b]{2}{*}{ Race } & \multirow[b]{2}{*}{ Biovar } & \multicolumn{2}{|c|}{ ELISA $^{c}$} & \multicolumn{2}{|c|}{$\mathrm{IF}^{\mathrm{d}}$} \\
\hline & & & & & & $\mathrm{scFv}$ & $\mathrm{PcA}$ & $\mathrm{scFv}$ & $\mathrm{PcA}$ \\
\hline R. solanacearum & Brazil & 1657 & PD1414 & 1 & 1 & - & + & - & nd \\
\hline R. solanacearum & Costa Rica & 1653 & PD507 & 1 & 3 & + & + & + & + \\
\hline R. solanacearum & Panama & 1655 & PD1255 & 1 & 3 & - & + & - & nd \\
\hline R. solanacearum & France & 1656 & PD1258 & 1 & 3 & - & + & - & nd \\
\hline R. solanacearum & France & 1669 & PD1256 & 1 & 3 & - & + & - & nd \\
\hline R. solanacearum & Indonesia & 1670 & PD278 & 1 & 3 & - & + & + & nd \\
\hline R. solanacearum & Hawaii & 1654 & PD508 & 1 & 4 & - & + & - & nd \\
\hline R. solanacearum & Japan & 1658 & PD1419 & 1 & 4 & + & + & + & + \\
\hline R. solanacearum & Panama & 1665 & PD1445 & 2 & 1 & - & + & - & nd \\
\hline R. solanacearum & Costa Rica & 1666 & PD1446 & 2 & 1 & - & + & - & nd \\
\hline R. solanacearum & Egypt & 933 & PD445 & 3 & 2 & + & + & + & + \\
\hline R. solanacearum & Netherlands & 1608 & PD2762 & 3 & 2 & + & + & + & + \\
\hline R. solanacearum & Netherlands & 1609 & PD2763 & 3 & 2 & + & + & + & + \\
\hline R. solanacearum & Netherlands & 1610 & PD2764 & 3 & 2 & + & + & + & + \\
\hline R. solanacearum & Egypt & 1661 & PD426 & 3 & 2 & + & + & + & + \\
\hline R. solanacearum & India & 1662 & PD1254 & 3 & 2 & + & + & + & + \\
\hline R. solanacearum & France & 1663 & PD1260 & 3 & 2 & + & + & + & + \\
\hline R. solanacearum & Chile & 1664 & PD1408 & 3 & 2 & + & + & + & + \\
\hline R. solanacearum & Netherlands & 1676 & PD2822 & 3 & 2 & + & + & + & + \\
\hline R. solanacearum & Netherlands & 1677 & PD2828 & 3 & 2 & + & + & + & + \\
\hline R. solanacearum & Netherlands & 1678 & PD2831 & 3 & 2 & + & + & + & + \\
\hline R. solanacearum & United Kingdom & 1681 & PD2474 & & 2 & + & + & + & + \\
\hline$R$. solanacearum & United Kingdom & 1684 & PD2477 & & 2 & + & + & + & + \\
\hline R. solanacearum? & Unknown & 1652 & NIZO96 & & & - & + & nd & nd \\
\hline R. solanacearum & France & 1711 & 1310 & & & + & + & + & + \\
\hline R. solanacearum & France & 1712 & 1361 & & & + & + & + & + \\
\hline
\end{tabular}

a Strains were obtained from J. D. Janse (Plant Protection Service, Wageningen, the Netherlands) and A. C. Le Roux (INRA, Rennes, France).

b IPO = Institute of Plant Protection, Wageningen, the Netherlands.

c ELISA signals: - = reaction below background; and + = strong reaction (at least threefold above background).

d IF signals: $-=$ no fluorescence $;+=$ strong fluorescence; and nd = not done. 
Purified scFvs anti-LPS 8, 12, and 13 gave high signals when tested in c-myc-ELISA with purified LPS (Fig. 5) and with $R$. solanacearum cells (data not shown), whereas a weak reaction was found with $\mathrm{scFv}$ anti-LPS 3. Similar results were obtained with IF. The scFvs anti-LPS 8, 12, and 13, but not scFv 3, gave bright fluorescent staining of $R$. solanacearum at $12.5 \mu \mathrm{g} / \mathrm{ml}$ (Fig. 6A) and brilliant fluorescence at $125 \mu \mathrm{g} / \mathrm{ml}$ (data not shown). It was confirmed that the scFvs indeed reacted with LPS of $R$. solanacearum by Western blotting, whereas no reaction with LPS from $R$. picketti was found (Fig. 6B).

The detection limit for $R$. solanacearum of scFv anti-LPS 12, the most reactive of the isolated scFvs, was comparable to polyclonal antiserum PcA-9523. In a double-antibody sandwich ELISA, both could detect as few as $4 \times 10^{4}$ cells per $\mathrm{ml}$ when in pure culture (Table 1). No difference in sensitivity was observed between the chromatogenic substrate p-NPP and the fluorogenic substrate FDP. The signals obtained were higher for PcA-9523 than for scFv anti-LPS 12, but the background value of scFv anti-LPS 12 was lower, especially when FDP substrate was used instead of $\mathrm{p}$-NPP.

To evaluate $\mathrm{scFv}$ anti-LPS 12 for use in routine tuber testing, $R$. solanacearum cells were diluted into a potato tuber extract and compared with serial dilutions of a pure culture. The lowest con- centration of $R$. solanacearum cells that could be detected in the sandwich ELISA with $\mathrm{scFv}$ anti-LPS 12 was $5 \times 10^{3}$ cells per ml in the potato tuber extract (Table 2). Even though high numbers of saprophytic bacteria were present in the tuber extract, the signals were only slightly reduced and the sensitivity was comparable to the pure culture.

Testing of the scFvs against $26 R$. solanacearum strains, both in ELISA and IF (Table 3), revealed that they reacted with all strains of race 3 , but only with some of the race 1 strains. No difference was observed between the specificities of the anti-LPS 8, anti-LPS 12, and anti-LPS $13 \mathrm{scFvs,}$ and, therefore, only the results with $\mathrm{scFv}$ anti-LPS 12 are shown.

The cross-reactivity of the recombinant antibodies was compared with PcA-9523 using a panel of plant-pathogenic and saprophytic bacteria (Table 4) that had been shown to cross-react with polyclonal antisera in ELISA, IF, or IFC. In ELISA and IF tests, scFvs cross-reacted with the BBD, R. syzygii, Serratia fonticola, two strains belonging to the Enterobacteriaceae, and an unidentified bacterial strain 1713, (Table 4). As was shown in Table 4, PcA-9523 cross-reacted with several bacterial strains that were not recognized by the scFvs. Thus, the specificity of the scFvs was higher than that of PcA-9523, the polyclonal antiserum that is used routinely for the detection of $R$. solanacearum in the Netherlands.

TABLE 4. Comparison of the reactivity of monoclonal single-chain variable antibody fragments (scFv) (anti-lipopolysaccharide [LPS] 12) and polyclonal antiserum (PcA-9523) with various bacterial strains in enzyme-linked immunosorbent assay (ELISA) and immunofluorescence cell staining (IF)

\begin{tabular}{|c|c|c|c|c|c|c|c|}
\hline \multirow{2}{*}{\multicolumn{4}{|c|}{ Strain }} & \multicolumn{4}{|c|}{ Immunoassay } \\
\hline & & & & \multicolumn{2}{|c|}{ ELISA $^{c}$} & \multicolumn{2}{|c|}{$\mathrm{IF}^{\mathrm{d}}$} \\
\hline Family $^{\mathrm{a}}$, genus or species & Origin & IPO number ${ }^{b}$ & Original number & $\mathrm{scFv}$ & PcA & $\mathrm{scFv}$ & PcA \\
\hline Ralstonia solanacearum & Netherlands & 1609 & PD2763 & + & + & + & + \\
\hline Banana blood disease & Sulawesi & S303 & PD2100 & + & + & + & + \\
\hline Ralstonia picketti & United Kingdom & 1720 & $\operatorname{Pr} 1150$ & - & + & - & + \\
\hline Ralstonia syzygii & Indonesia & S302 & PD2093 & + & + & + & + \\
\hline Pseudomonas marginalis pv. marginales & France & 1714 & CFBP1538 & - & + & - & - \\
\hline Unknown & France & 1713 & 1531 & + & + & - & - \\
\hline Ochrobactrum antropi & Spain & 1682 & 1521101 & - & - & - & - \\
\hline Rathayibacter tritici & Spain & 1690 & 15803 & - & + & - & + \\
\hline Bacillus macerans & Spain & 1691 & 15803 & - & - & - & - \\
\hline Aureobacterium liquefaciens & Spain & 1692 & 15807 & - & + & - & - \\
\hline Aureobacterium liquefaciens & Spain & 1693 & 158010 & - & + & - & + \\
\hline Serratia fonticola & Spain & 1694 & 1534.c & + & + & + & + \\
\hline Ralstonia & Netherlands & 1723 & PD2778 & - & - & - & + \\
\hline Unknown & France & 1715 & R3 & - & - & - & + \\
\hline Ochrobactrum antropi & Unknown & S306 & PD2808 & - & - & - & + \\
\hline Enterobacteriaceae & Netherlands & S339 & PK15a & + & + & + & + \\
\hline Rhodococcus & Netherlands & S340 & PK10a & - & - & - & - \\
\hline Xanthomonas maltophilia & Netherlands & S341 & PK06b/b & - & - & - & - \\
\hline Enterobacteriaceae & Netherlands & S342 & IV137 & + & + & + & + \\
\hline Erwinia herbicola & Netherlands & S343 & PK18a & - & - & - & - \\
\hline Enterobacteriaceae & Netherlands & S345 & PK04a & - & - & - & + \\
\hline Bacillus & Netherlands & S346 & PK2/455 & - & - & - & + \\
\hline Rhodococcus & Netherlands & S347 & PK2/76c & - & - & - & - \\
\hline Unknown & Sweden & S348 & PK2/76b & - & - & - & + \\
\hline Bacillus polymyxa & France & 1721 & CFBP1954 & - & - & - & - \\
\hline Ochrobactrum antropi & United Kingdom & 1722 & T-3b-7 & - & + & - & - \\
\hline Sphingobacterium multivorum & Unknown & 1717 & R1c-3a & - & - & - & - \\
\hline Erwinia carotovora subsp. carotovora & France & 1710 & 233 & - & - & - & + \\
\hline Burkholderia andropogonis & United Kingdom & 1704 & NCPPB1127 & - & + & - & - \\
\hline Burkholderia caryophylli & United Kingdom & 1705 & NCPPB2151 & - & + & - & + \\
\hline Burkholderia caryophylli & United Kingdom & 1701 & NCPPB353 & - & - & - & + \\
\hline Burkholderia cepacia & United Kingdom & 1702 & NCPPB945 & - & - & - & - \\
\hline Burkholderia cepacia & United Kingdom & 1703 & NCPPB946 & - & + & - & - \\
\hline Burkholderia cepacia & Unknown & 1718 & R5d-1 & - & - & - & - \\
\hline Burkholderia glumae & United Kingdom & 1708 & NCPPB3708 & - & + & - & + \\
\hline Burkholderia plantarii & United Kingdom & 1707 & NCPPB3590 & - & - & - & + \\
\hline
\end{tabular}

${ }^{a}$ Fatty acid analysis was used for strain identification, and the best matches with the database of the Microbial Identification System are given. Sometimes characterization was only up to the family level as no closer match (at least 50\% identity) was found. Strains were obtained from J. D. Janse (Plant Protection Service, Wageningen, the Netherlands), M. M. Lopez (IVIA, Valencia, Spain), A. C. Le Roux (INRA, Rennes, France), and J. G. Elphinstone (Central Science Laboratory, York, United Kingdom).

${ }^{\mathrm{b}} \mathrm{IPO}=$ Institute of Plant Protection, Wageningen, the Netherlands.

${ }^{c}$ ELISA signals: $-=$ reaction below background; and $+=$ strong reaction (at least threefold above background).

${ }^{\mathrm{d}}$ IF signals: $-=$ no fluorescence; $+=$ strong fluorescence; and $\mathrm{nd}=$ not done. 


\section{DISCUSSION}

Four different scFvs were isolated from a combinatorial antibody library and evaluated for their use in a diagnostic assay for the detection of $R$. solanacearum race 3. Three of these, anti-LPS 8, anti-LPS 12, and anti-LPS 13, were promising candidates for routine application based on their ease of production in E. coli and their specificity in IF and ELISA. The affinity of anti-LPS 12 was sufficient for sensitive detection of $R$. solanacearum; threshold levels between $5 \times 10^{3}$ and $4 \times 10^{4}$ bacteria per ml were reached in ELISA and bright fluorescent staining was achieved in IF.

The selected antibodies showed a higher degree of specificity than did PcA-9523, the polyclonal antiserum that is currently used in routine testing. Apparently, the LPS epitopes recognized by the scFvs do not occur as frequently in the bacteria tested (Table 4) as do other epitopes recognized by PcA-9523. It is interesting that all four different $\mathrm{scFvs}$ recognize the same bacterial strains and, therefore, probably react with the same epitope. However, this was not validated, as no epitope mapping was carried out. The cross-reactions (Table 4) observed with $\mathrm{BBD}$ and $R$. syzygii will not compromise a diagnostic test for potato brown rot, because these species are not present in temperate areas where this test will be used. In contrast, the cross-reactions observed with the four other saprophytic bacteria from potato and soil can possibly cause false-positive results, because they have been isolated in temperate areas. However, as the number of cross-reacting species is reduced relative to the PAbs in PcA-9523, it is anticipated that the use of these antibodies in seed testing will result in a decreased number of false positives.

The sensitivity observed in ELISA, comparable to high quality PAbs, is promising. In IF, relatively high quantities of scFv were required to obtain the same signal as the PAbs. This is probably because the scFvs have one antigen-binding site and bind monovalently to the antigen. In contrast, full-size antibodies have two antigen-binding sites that can bind with two epitopes simultaneously. According to Neri et al. (19), this avidity effect can increase binding up to 100-fold and results in improved performance in immunoassays. Single-chain antibodies can be engineered in a format allowing bivalent binding (21). Bivalent molecules can also be established through a genetic fusion with $E$. coli alkaline phosphatase, a dimeric enzyme $(13,14)$. Thus, if one of these avidity effects is added, it may further increase the sensitivity of our immunoassay. Alkaline phosphatase may be the most convenient choice for detection purposes. The production of $\mathrm{scFv}$ enzyme fusion proteins may result in improved reproducibility for the detection of antigens in various immunoassays, since the variation due to repeated antibody enzyme conjugation is avoided.

Engineering the format of scFvs might also be advantageous for the development of routine assays for the detection of $R$. solanacearum. Single-chain antibodies are small molecules that are often inactivated upon coating to ELISA plates (12). Fusion to large proteins like gluthatione- $S$-transferase, amphipathic helices, or to other immunoglobulin domains may enhance the coating efficiency while retaining the full binding activity (12).

The monoclonal recombinant scFvs described here are applicable in routine assays for $R$. solanacearum race 3, even though some cross-reactions with other species were observed. The selection of other anti-LPS scFvs that do not cross-react with these strains remains an option. The difficulty lies in the nature of the LPS of the cross-reacting bacteria. Although LPS are highly variable molecules, the possibility cannot be excluded that LPS epitopes of cross-reacting bacteria are at least partially identical to the target bacteria. For the isolation of even more specific antibodies, consideration may be given to outer membrane proteins or extracellular polysaccharides as antigens. We used a straightforward selection protocol that resulted in the most specific antibodies found thus far for $R$. solanacearum race 3 . However, phage display allows easy adaptation of the selection protocols such as the inclusion of cycles of negative (against unwanted bacteria) and positive (for different races) selection. In addition, the current antibody libraries cover the complete immune repertoire, in contrast to the hybridoma technology in which only a part of the immune repertoire is tested. Antibody phage display in combination with protein engineering is highly promising for the selection of tailor-made MAbs and can be combined with the design of improved immunoassays for phytopathogenic bacteria.

\section{ACKNOWLEDGMENTS}

This research was supported by grants from the Program Committee for Agriculture and Biotechnology and the Dutch Potato Industries. We thank H. Hoogenboom for allowing us to work at his laboratory (CESAME, Academic Hospital Maastricht, the Netherlands) with the Vaughan antibody library developed by Cambridge Antibody Technology. We also thank W. B. van Muiswinkel (Wageningen Institute of Animal Sciences, Cell Biology and Immunology Group, Wageningen Agricultural University) for critically reading the manuscript.

\section{LITERATURE CITED}

1. Alvarez, A. M., and Benedict, A. A. 1990. Monoclonal antibodies for the identification of plant pathogenic bacteria: Potential applications to Ralstonia solanacearum. Pages 26-31 in: Bacterial Wilt of Groundnut. K. J. Middleton and A. C. Hayward, eds. ACIAR Proc. 31. Australian Centre for International Agricultural Research (ACIAR), Canberra, Australia.

2. Alvarez, A. M., Berestecky, J. I., Stiles, J. I., Ferreira, S. A., and Benedict, A. A. 1993. Serological and molecular approaches to identification of Pseudomonas solanacearum strains from Heliconia. Pages 6269 in: Bacterial Wilt, International Conference (1992), Kaoshiuing, Taiwan. ACIAR Proc. 45. Australian Centre for International Agricultural Research (ACIAR), Canberra, Australia.

3. Clark, M. F., and Adams, A. N. 1977. Characteristics of the microplate method of enzyme-linked immunosorbent assay for the detection of plant viruses. J. Gen. Virol. 34:475-483.

4. De Weger, L. A., Jann, B., Jann, K., and Lugtenberg, B. 1987. Lipopolysaccharides of Pseudomonas spp. that stimulate plant growth: Composition and use for strain identification. J. Bacteriol. 169:1441-1446.

5. Elphinstone, J. G., Hennessy, J., Wilson, J. K., and Stead, D. K. 1996. Sensitivity of different methods for the detection of Ralstonia solanacearum (Smith) Smith in potato tuber extract. OEPP (Organ. Eur. Mediterr. Prot.)/EPPO (Eur. Mediterr. Plant Prot. Organ.) Bull. 26:663-678.

6. Griffiths, A. D., Williams, S. C., Hartley, O., Tomlinson, I. M., Waterhouse, P., Crosby, W. L., Kontermann, R. E., Jones, P. T., Low, N. M., Allison, T. J., Prospero, T. D., Hoogenboom, H. R., Nissim, A., Cox, J. P. L., Harrison, J. L., Zaccolo, M., Gherardi, E., and Winter, G. 1994. Isolation of high affinity antibodies directly from large synthetic repertoires. EMBO (Eur. Mol. Biol. Organ.) J. 13:3245-3260.

7. Hayward, A. C. 1991. Biology and epidemiology of bacterial wilt, caused by Ralstonia solanacearum. Annu. Rev. Phytopathol. 29:65-87.

8. He, L. Y. 1986. Bacterial wilt in the People's Republic of China. Pages 40-48 in: Bacterial Wilt Disease and the South Pacific. G. J. Persley, ed. ACIAR Proc. 13. Australian Centre for International Agricultural Research (ACIAR), Canberra, Australia.

9. Hoogenboom, H. R., Griffiths, A. D., Johnson, K. S., Chiswell, D. J., Hudson, P., and Winter, G. 1991. Multi-subunit proteins on the surface of filamentous phage: Methodologies for displaying antibody (Fab) heavy and light chains. Nucleic Acids Res. 15:4133-4137.

10. Huston, J. S., Levinson, D., Mudgett-Hunter, M., Tai, M., Novotny, J., Margolies, M. N., Ridge, R. J., Bruccoleri, R. E., Haber, E., Crea, R., and Oppermann, H. 1988. Protein engineering of antibody binding sites: Recovery of specific activity in an anti-digoxin single-chain Fv analogue produced in Escherichia coli. Proc. Natl. Acad. Sci. U.S.A. 85:5879-5883.

11. Janse, J. D. 1988. A detection method for Ralstonia solanacearum in symptomless potato tubers and some data on its sensitivity and specificity. OEPP (Organ. Eur. Mediterr. Prot.)/EPPO (Eur. Mediterr. Plant Prot. Organ.) Bull. 18:343-351.

12. Kerschbaumer, R. J., Hirschl, S., Kaufman, A., Ibl, M., Koenig, R., and Himmler, G. 1997. Single-chain Fv fusion proteins suitable as coating and detecting reagents in a double antibody sandwich enzyme-linked immunosorbent assay. Anal. Biochem. 249:219-227.

13. Kerschbaumer, R. J., Hirschl, S., Schwager, C., Ibl, M., and Himmler, G. 1996. PDAP2: A vector for construction of alkaline phosphatase fusionproteins. Immunotechnology 2:145-150.

14. Kohl, J., Rüker, F., Himmler, G., and Katinger, H. 1990. Cloning and expression of an HIV-1 specific single-chain Fv region fused to Es- 
cherichia coli alkaline phosphatase. Ann. N.Y. Acad. Sci. 646:106-114.

15. Lindner, P., Guth, B., Wuelfing, C., Krebber, C., Steipe, B., Mueller, F., and Plückthun, A. 1992. Purification of native proteins from the cytoplasm and periplasm of Escherichia coli using IMAC and histidine tails: A comparison of proteins and protocols. Methods 4:41-56.

16. McCafferty, J., Griffiths, A. D., Winter, G., and Chiswell, D. J. 1990. Phage-antibodies: Filamentous phage displaying antibody variable domains. Nature 348:552-554.

17. McGarvey, J. A., Bell, C. J., Denny, T. P., and Schell, M. A. 1998. Analysis of extracellular polysaccharide-I in culture and in planta using immunological methods: New insights and implications. Pages 157-163 in: Bacterial Wilt Disease: Molecular and Ecological Aspects. P. Prior, C. Allen, and J. Elphinstone, eds. Springer-Verlag, Berlin.

18. Munro, S., and Pelham, H. R. B. 1986. An Hsp-70 like protein in the ER: Identity with the $78 \mathrm{kD}$ glucose-regulated protein and immunoglobulin heavy chain binding protein. Cell 46:291-300.

19. Neri, D., Momo, M., Prospero, T., and Winter, G. 1995. High-affinity antigen binding by chelating recombinant antibodies (CRABS). J. Mol. Biol. 246:367-373.

20. Orlandi, O., Gussow, D. H., Jones, P. T., and Winter, G. 1989. Cloning immunoglobulin variable domains for the expression by the polymerase chain reaction. Proc. Natl. Acad. Sci. U.S.A. 86:3833-3837.

21. Pack, P., and Plückthun, A. 1992. Miniantibodies: Use of amphipathic helices to produce functional, flexibly linked dimeric Fv fragments with high avidity in Escherichia coli. Biochemistry 31:1579-1584.

22. Robinson-Smith, A., Jones, P., Elphinstone, J. G., and Forde, S. M. D. 1995. Production of antibodies to Ralstonia solanacearum, the causative agent of bacterial wilt. Food Agric. Immunol. 7:67-79.

23. Sambrook, J., Fritsch, E. F., and Maniatis, T. 1990. Molecular Cloning: A Laboratory Manual. Cold Spring Harbor Laboratory, Cold Spring Harbor, NY.
24. Sastry, L., Alting-Mees, M., Huse, W. D., Short, J. M., Sorge, J. A., Hay, B. H., Janda, K. D., Benkovic, S. J., and Lerner, R. A. 1989. Cloning of the immunological repertoire in Escherichia coli for generation of monoclonal catalytic antibodies: Construction of a heavy chain variable regionspecific cDNA library. Proc. Natl. Acad. Sci. U.S.A. 86:5728-5732.

25. Seal, S. E., and Elphinstone, J. G. 1994. Advances in identification and detection of Ralstonia solanacearum. Pages 35-58 in: Bacterial Wilt: The Disease and Its Causative Agent, Ralstonia solanacearum. A. C. Hayward and G. L. Hartman, eds. CAB International, Wallingford, United Kingdom.

26. Smith, J. J., Offord, L. C., Hoderness, M., and Saddler, G. S. 1995. Genetic diversity of Burkholderia solanacearum (synonym Ralstonia solanacearum) race 3 in Kenya. Appl. Environ. Microbiol. 61:4263-4268.

27. Stead, D. E. 1996. Bacterial diseases of potatoes-future problems? Pages 303-311 in: Proceedings Crop Protection in Northern Britain 1996.

28. Tijsen, P. 1985. Preparation of enzyme-antibody or other enzyme-macromolecule conjugates. Pages 1-20 in: Laboratory Techniques in Biochemistry and Molecular Biology. Vol. 15. Practice and Theory of Enzyme Immunoassays. R. H. Burdon and P. H. van Knippenberg, eds. Elsevier Publishing, Amsterdam.

29. van der Wolf, J. M., van Beckhoven, J. R. C. M., De Boef, E., and Roozen, N. J. M. 1993. Serological characterization of fluorescent Pseudomonas strains cross-reacting with antibodies against Erwinia chrysanthemi. Neth. J. Plant Pathol. 99:51-60.

30. Vaughan, T. J., Williams, A. J., Pritchard, K., Osbourn, J. K., Pope, A. R., Earnshaw, J. C., McCafferty, J., Hodits, R. A., Wilton, J., and Johnson, K. 1996. Human antibodies with sub-nanomolar affinities isolated from a large non-immunized phage display library. Nature Biotechnol. 14:309-314.

31. Woods, A. C. 1984. Moko disease: Atypical symptoms induced by afluidal variants of Pseudomonas solanacearum in banana plants. Phytopathology 74:972-976. 